\title{
RESULTS FROM A SOIL IMPROVEMENT AND FERTILIZING TEST ON FEN LAND AT LETEENSUO
}

\author{
YRJÖ Pessi \\ Society of Peat Cultivation, Experimental Station Leteensuo.
}

Received August 22, 1961

At the Experimental Station of Leteensuo several soil improvement and fertilizing tests on fen and Sphagnum bog were established already at an early stage of its activity. The results of these tests over prolonged periods have been reported in a number of papers published in recent years $(2,3,4,5,6,8,9)$. An extensive, combined soil improvement and fertilizing test was established in 1910 by Simola, but its results have so far been reported only with respect to fairly short periods $(7,10,11)$. The following is a report of the results obtained in this test during the period 1910-1960.

\section{Test area}

The peat of the test area is forest sedge peat; the bog type prior to the clearing of the area was a grassy spruce and broad-leaved tree swamp rich in herbs. The peat layer has a depth of more than 2 metres. This area has been drained by means of open ditches, dividing it into strips $20 \mathrm{~m}$ in width.

The quality of the peat is reflected by the results of the analysis stated in Vesikivi's (10, p. 32) investigation, which also gives an account of the results of the analysis relating to the clay and sand used as soil improving agents (loc.cit., p. 34).

\section{Procedure}

The test area was cleared for cultivation in 1909 and the soil improving agents were spread in the winter of $1909 / 1910$. The quantities of clay or sand were 0,100 , 200,300 and $400 \mathrm{~m}^{3}$ per hectare. The claying or sand addition was repeated according to the same schedule in the early spring of 1928. The soil improving agents were spread uniformly over each strip between the ditches $(10 \mathrm{~m} \times 100 \mathrm{~m})$.

Various kinds of experimental phosphate and potassium fertilizations were combined with the soil improving treatment. Nitrogen fertilization is redundant 
on the bog in question. The annual phosphate fertilizer additions were $50(\mathrm{P})$ and 100 (2 P) $\mathrm{kg} \mathrm{P}_{2} \mathrm{O}_{5}$ per hectare in the years 1910-1927; from 1928 onwards the quantities of 40 and $80 \mathrm{~kg}$ per hectare, respectively, were applied. The fertilizing agent was superphosphate. The potassium fertilization consisted of $100 \mathrm{~kg} \mathrm{~K}_{2} \mathrm{O}(\mathrm{K})$ per hectare, as potassium salt, throughout the test period. In 1917 no fertilizers were given, and in 1918 only the phosphate fertilizer was given at half the abovementioned dosage. The detailed location of the test plots is shown in Fig. 1.

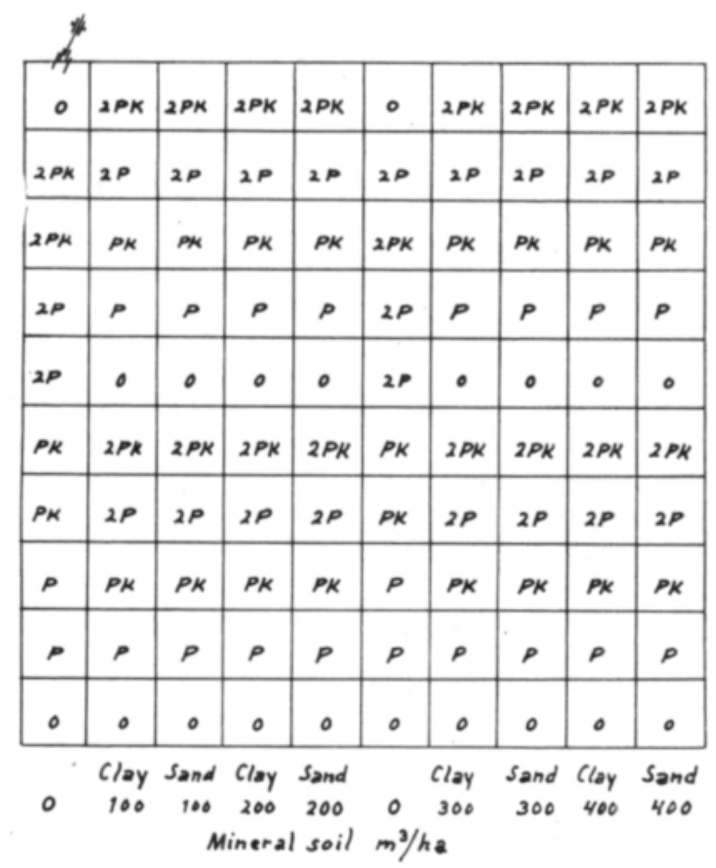

Fig. 1. The position of plots in the test.

\section{Crop yield results}

The weather conditions of almost the entire test period can be found in another publication (2).

The annual test results are shown in tables in the Appendix, which is deposited in the Agricultural Library of the University of Helsinki and in the Office of the Peat Cultivation Society, Leteensuo.

Meadows. - Tables 1, 2 and 3 give the results of the tests as mean values of the hay crop yield; Table 1 showing the mean crop yield figures referring to the period prior to the repetition of the soil improving treatment (the period 1910-1927), Table 2 those for the period after the second treatment (1928-1960), and Table 3 states the means for the entire test period. Some of the results are further graphically illustrated in Figs. 2 and 3. 


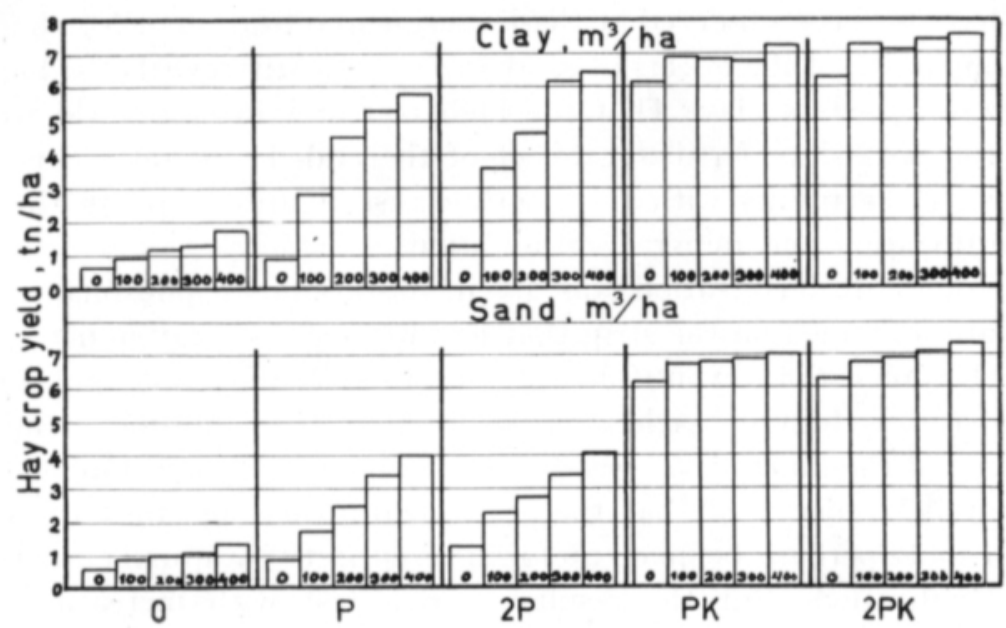

Fig. 2. Average annual hay crop yields (29 years), during the entire test period.

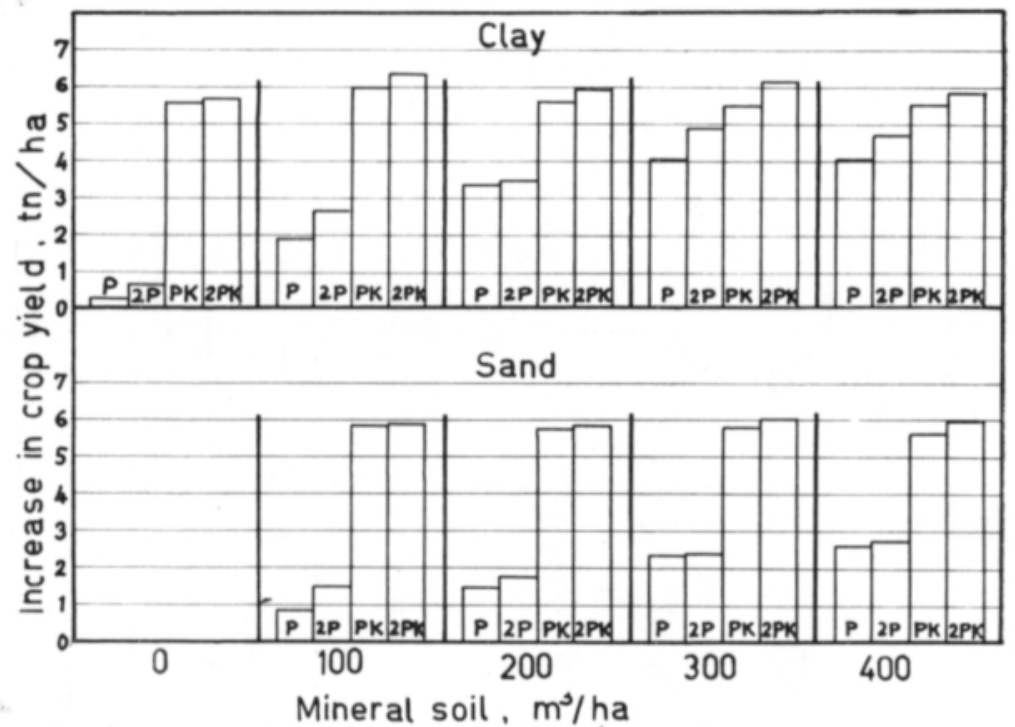

Fig. 3. Incerases of hay crop yields per year caused by various fertilizing combined with various soil improving, during the entire test period.

The effect of the soil improving treatment on the hay crops can be most conveniently studied with the aid of Fig. 2. It can be seen, for instance, that the soil improving agents had little effect and the crop yields were low when no fertilizers were applied. When phosphate fertilization was administered, the crops increased in a decisive degree with the increasing quantity of the soil improving agents.

In this instance, the beneficial effect of the soil improving agents on the crop yield is largely due to the potassium fertilizing effect of the added mineral soil, a 
fact which has also been observed at the Experimental Station of Northern Pohjanmaa (1). Comparison of the effects of sand and clay clearly reveals the higher potassium fertilizing effect of clay. That the high increases in crop yield were indeed caused by the potassium fertilizing effect of the added mineral soil is obvious if one compares these results with the crop increase figures found in the test plots with PK fertilization and mineral soil addition.

When potassium fertilization was given in addition to phosphates, good hay crops were also obtained on the strip that had not received any mineral soil. However, it can be noted that, even if no potassium fertilization was applied, a certain further increase of the crop yield was produced by the addition of mineral soil, while the type of the mineral soil was by then no longer of importance.

It might be conjectured that the crop yield-increasing effect of the mineral soil addition could perhaps be made up for in its entirety by a further increase in the potassium fertilization. But the results from a test with increasing potassium quantities and soil improvement, established adjacent to the test under consideration, have shown that the increases in crop yield produced by mineral soil addition did not progress any further with increasing potassium quantities $(4, \mathrm{p} .232)$. The beneficial effect of mineral soil is therefore thought to be due also to other factors besides its fertilizing action, and it seems unlikely that any substitution can be made for these effects.

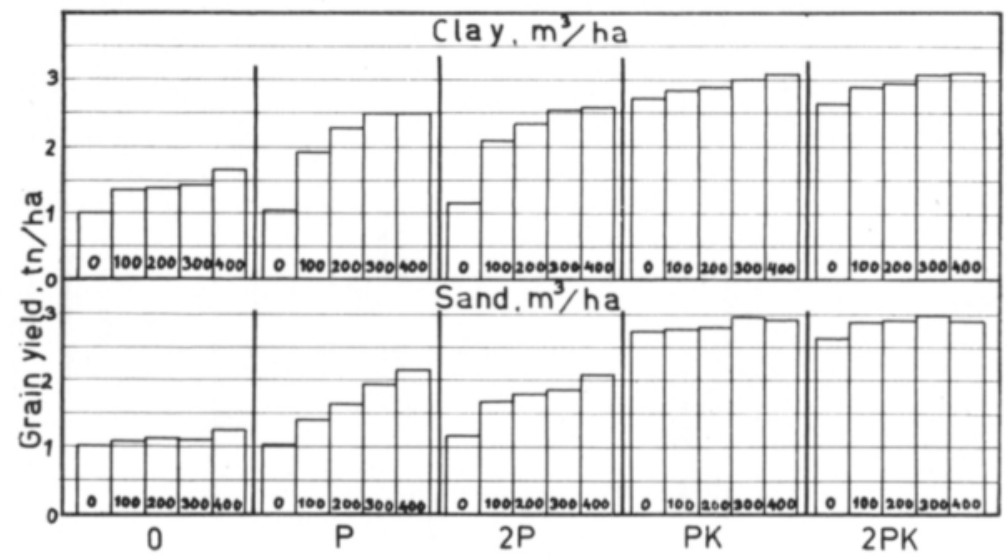

Fig. 4. Avergae annual grain yields of oats (11 years) during the entire test period.

In investigating the significance of fertilization, the observation can be made in the first place that both phosphate and potassium fertilization is indispensable if no soil improving agent has been given. Particularly owing to the high potassium fertilizing effect of mineral soil, especially of clay, fairly good crop yields are already obtained with phosphate fertilization alone if soil improvement has been done. Clay in particular has a surprisingly good potassium fertilizing effect. However, potassium fertilization is also required. 
Oats. - The mean crop yields of oats per year have been tabulated in Tables 4, 5 and 6 and illustrated in Fig. 4. On the whole, the soil improving agents and fertilizers have produced effects similar to the case of hay. Comparison of these results with the results from the other fertilizing and soil improvement tests performed at Leteensuo $(4,6,9)$ reveals a uniform tendency.

Duration of the effect of soil improvement. - As has been said in the description of the test, soil improving agents were applied twice in this test, namely, in the years 1910 and 1928. The latest application was thus about 30 years ago. Fig. 5 shows the increases in crop yield produced by clay and sand additions $400 \mathrm{~m}^{3}$ per hectare at 2 PK fertilization, as means of five-year periods. The fodder unit equivalents are the same as in a previous investigation (2). The graph reveals that the crop yield

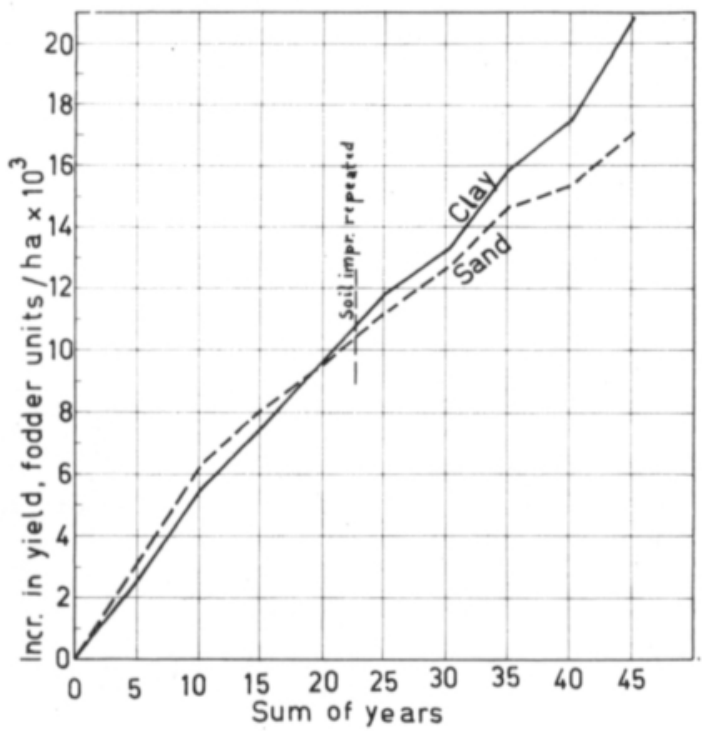

Fig. 5. The increases of yield caused by the clay and sand addition $400 \mathrm{~m}^{3}$ per hectare. The increases of yield have been calculated from 5-years periods.

increases produced by the soil improvement have remained constant during the last decades, and no drop in the crop yield increase can be noted. It is thus evident that the soil improvement has a fairly prolonged effect. This is also borne out by the investigation of ANTTINEN (1) as well as by several other tests carried out at Leteensuo $(2,6)$.

\section{Conclusions}

Clay and sand, used as soil improving agents, have increased the hay crops as well as the cereal crops. When the fertilization contained phosphates only, the increases in crop yield produced by the soil improvement were quite high. In this case clay developed a higher effect than sand. In connection with phosphate plus potassium fertilization both kinds of mineral soil were approximately equal in value, but 
their effect fell considerably below that of phosphate fertilization alone. These agents have thus a remarkable potassium fertilizing effect. However, potassium fertilization was not able to account for the entire crop yield-increasing effect of mineral soil.

The highest increases in crop yield per unit of mineral soil addition were obtained with the mineral soil quantity of $100 \mathrm{~m}^{3}$ per hectare.

The addition of mineral soil has a prolonged effect since the effect has not decreased in the 30 years since the latest soil improving treatment in this test.

Phosphate and potassium fertilization are both necessary. For spring cereals and for the annual top dress fertilization of hay meadows the superphosphate quantity of $200-300 \mathrm{~kg}$ per hectare is adequate. The requirement of potassium fertilizer varies according to the quantity of soil improving agents and their quality. In all circumstances $200 \mathrm{~kg} 50 \%$ potassium salt per hectare seems to be a sufficient potassium fertilization for the plants considered in this test. A slightly higher quantity is thought to be necessary for the top dress fertilization of hay meadows without soil improving agents.

\section{REFERENCES}

(1) Antrinen, O. 1957. Saraturvesuon saveus- ja lannoituskokeen tuloksia. Referat: Ergebnisse eines Lehmzufuhr- und Düngungsversuchs auf Seggentorfmoor. Valt. maatal. koetoim. julk. 163: $1-20$.

(2) Pessi, Y. 1959. Kivennäismaan vaikutuksesta rahkasuon maanparannusaineena Leteensuon koeaseman pitkäaikaisten kenttäkokeiden perusteella. Summary: On the effect of mineral soil as a soil improving agent on Sphagnum bogs on the basis of prolonged field tests at Leteensuo Experimental Station. Acta agr. fenn. 94, 14: 241-268.

(3) - $\quad$ 1959. Mutasuon kalkituskokeiden tuloksia Leteensuolta. Summary: The results of liming tests on fen at Leteensuo. Maat. tiet. aikak. 31: 285-293.

(4) -1960 . Fen fertilization with potash in the light of tests at Leteensuo Experimental Station. Selostus: Mutasuon kalilannoituksesta Leteensuon kokeiden perusteella. Ibid. 32: 229-238.

(5) - 1960. Fertilization of Sphagnum bogs on the basis of certain field experiments at Leteensuo. Selostus: Rahkasuon lannoitus eräiden Leteensuon kokeiden perusteella. Ibid. 32: 144-157.

(6) - 1960. Kivennäismaan merkityksestä mutasuon maanparannusaineena Leteensuon koeaseman pitkäaikaisten kenttäkokeiden perusteella. Summary: On the significance of mineral soil as a soil improving agent on fens on the basis of prolonged field tests at Leteensuo Experimental Station. Acta agr. fenn. 95, 3.

(7) Siмоца, E. F. 1923. Uber die Ernteerträge und die Ausdauer von reinem Timothee- und von Mischgras auf einem Niederungsmoor mit und ohne Lehm und Sand bei Benutzung verschiedener Düngungen während des Zeitraumes 1916-1922. Suom. suovilj. yhd. tiet. julk. 4: 1-127.

(8) Táala, M. 1958. Suoviljelysten fosfaattilannoituksesta. Summary: On phosphate fertilization Peat Soil. Suovilj.yhd. vuosik. 63: 30-38.

(9) - -1961 . Super-, thomas- ja hienofosfaatin vaikutuksesta mutasuolla. Summary: On-the effects of superphosphate, basic slag and hyperphosphate on fen soil. Maat. tiet. aikak. 33: $57-64$. 
(10) Vesikivi, A. 1929. Suonsavetuksen ja -hiekoituksen taloudellisesta kannattavaisuudesta. Metodia selvittävä tutkimus. Referat: Uber die Rentabilität der Lehm- und Sandmischkultur auf Moorboden. Suom. suovilj.yhd.tiet.julk. 12: 1-131.

(11) - 1933. Suonsavetuksen ja -hiekoituksen lannoitusvaikutuksesta. Referat: Ủber die Düngewirkung der Lehm- und Sandmischungen auf Moorboden. Ibid. 14: 1-29.

S E L O T U S:

MUTASUON MAANPARANNUS- JA LANNOITUSKOKEEN TULOKSIA LETEENSUOLTA

YRJö Pessı

Suoviljelysyhdistys, Leteensuon koeasema

Maanparannusaineena käytetty savi ja hiekka ovat lisänneet sekä heinä- että viljasatoja. Kun lannoituksena on ollut vain fosfaattilannoitus, ovat maanparannuksen aiheuttamat sadonlisăykset olleet suuria. Tällöin saven vaikutus on ollut suurempi kuin hiekan. Fosfaattikalilannoituksen yhteydessä molemmat kivennäismaat ovat olleet jokseenkin samanveroisia. Niiden vaikutus ei ole ollut kuitenkaan läheskäån yhtä suuri kuin pelkän fosfaattilannoituksen yhteydessä. Niillä, ja varsinkin savella on siis huomattava kalilannoitusvaikutus. Kalilannoitus ei ole kuitenkaan täysin korvannut kivennäismaan satoalisäävää vaikutusta.

Lisättyă kivennäismaayksikköä kohti on saatu suurimmat sadonlisäykset maanparannusmäärällă $100 \mathrm{~m}^{3} / \mathrm{ha}$.

Kivennäismaan vaikutusaika on pitkä. Vaikutus ei ole vähentynyt 30 vuoden kuluessa, mikä aika on kulunut viimeisestä maanparannuskäsittelystä.

Sekä fosfaatti- että kalilannoitus ovat tarpeellisia. Kevätviljoille ja nurmen vuotuiseen pintalannoitukseen on superfosfaattimäärä $200-300 \mathrm{~kg} / \mathrm{ha}$ riittävä. Kalilannoituksen tarve vaihtelee käytetyn maanparannusaineen määrästä ja laadusta johtuen. Kaikissa olosuhteissa lienee mainituille kasveille riittävä kalilannoitus $200 \mathrm{~kg} / \mathrm{ha}$ 50-prosenttista kalisuolaa. Nurmen pintalannoitukseen ilman maanparannusainetta tarvittaneen vähän enemmän.

A p pendix

Table 1. Average annual hay crop yields (10 years), kg per hectare, during the period $1910-1927$.

\begin{tabular}{|c|c|c|c|c|c|c|c|}
\hline \multicolumn{2}{|c|}{$\begin{array}{l}\text { Mineral soil, } \\
\mathrm{m}^{3} \text { per hectare }\end{array}$} & 0 & $\mathbf{P}$ & $2 \mathrm{P}$ & PK & $2 \mathrm{PK}$ & Mean \\
\hline & 0 & 600 & 800 & 1300 & 5570 & 6310 & 2950 \\
\hline Clay & 100 & 1100 & 2850 & 3610 & 6780 & 7730 & 4420 \\
\hline, & 200 & 1220 & 4080 & 4390 & 6580 & 7590 & 4770 \\
\hline , & 300 & 1280 & 4360 & 5550 & 6160 & 7520 & 4970 \\
\hline , & 400 & 1730 & 4910 & 5770 & 6910 & 7550 & 5370 \\
\hline Sand & 100 & 1050 & 1870 & 2740 & 6260 & 6810 & 3750 \\
\hline , & 200 & 1150 & 2560 & 2810 & 6600 & 6910 & 4010 \\
\hline , & 300 & 1130 & 3290 & 3320 & 6240 & 7140 & 4270 \\
\hline , & 400 & 1340 & 3760 & 3960 & 6580 & 7510 & 4630 \\
\hline Mean & & 1180 & 3160 & 3720 & 6410 & 7230 & 4340 \\
\hline
\end{tabular}

Fertilizing 223* 294** 375***

Mineral soil 229*393** 502*** 
Table 2. Average annual hay crop yields (19 years), kg per hectare, during the period $1928-1960$

\begin{tabular}{|c|c|c|c|c|c|c|c|}
\hline \multicolumn{2}{|c|}{$\begin{array}{l}\text { Mineral soil, } \\
\mathrm{m}^{3} \text { per hectare }\end{array}$} & 0 & $\mathrm{P}$ & $2 \mathrm{P}$ & PK & $2 \mathrm{PK}$ & Mean \\
\hline & 0 & 600 & 870 & 1180 & 6420 & 6190 & 3060 \\
\hline Clay & 100 & 810 & 2750 & 3520 & 6910 & 6940 & 4200 \\
\hline 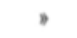 & 200 & 1180 & 4720 & 4720 & 6900 & 6850 & 4880 \\
\hline . & 300 & 1220 & 5780 & 6450 & 7010 & 7300 & 5350 \\
\hline 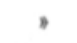 & 400 & 1670 & 6190 & 6730 & 7320 & 7540 & 5900 \\
\hline Sand & 100 & 770 & 1610 & 2160 & 6920 & 6740 & 3640 \\
\hline 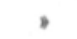 & 200 & 890 & 2420 & 2720 & 6820 & 6800 & 3930 \\
\hline , & 300 & 980 & 3430 & 3440 & 7120 & 7000 & 4400 \\
\hline, & 400 & 1310 & 4100 & 4120 & 7200 & 7200 & 4780 \\
\hline Mean & & 1050 & 3440 & 3900 & 6970 & 6970 & 4480 \\
\hline
\end{tabular}

Fertilizing $186 * 245 * * 313 * * *$

Mineral soil $252 * 332 * * 424 * * *$

Table 3. Average annual hay crop yields (29 years), $\mathrm{kg}$ per hectare, during the entire test period

\begin{tabular}{|c|c|c|c|c|c|c|c|}
\hline \multicolumn{2}{|c|}{$\begin{array}{l}\text { Mineral soil, } \\
\mathrm{m}^{3} \text { per hectare }\end{array}$} & 0 & $\mathrm{P}$ & $2 \mathrm{P}$ & PK & $2 \mathrm{PK}$ & Mean \\
\hline & 0 & 600 & 850 & 1230 & 6130 & 6270 & 3020 \\
\hline Clay & 100 & 910 & 2790 & 3550 & 6880 & 7240 & 4280 \\
\hline , & 200 & 1190 & 4500 & 4610 & 6810 & 7110 & 4840 \\
\hline , & 300 & 1240 & 5290 & 6140 & 6730 & 7390 & 5360 \\
\hline , & 400 & 1690 & 5740 & 6410 & 7200 & 7540 & 5720 \\
\hline Sand & 100 & 870 & 1700 & 2360 & 6710 & 6760 & 3680 \\
\hline , & 200 & 980 & 2470 & 2750 & 6750 & 6840 & 3960 \\
\hline , & 300 & 1030 & 3390 & 3400 & 6820 & 7050 & 4340 \\
\hline , & 400 & 1320 & 3980 & 4060 & 6980 & 7310 & 4730 \\
\hline Mean & & 1090 & 3410 & 3830 & 6780 & 7060 & 4440 \\
\hline
\end{tabular}

Fertilizing 156* 204** 261***

Mineral soil $208^{*} 273^{* *} 349 * * *$ 
Table 4. Average annual grain and straw yields of oats (6 years), $\mathrm{kg}$ per hectare, during the period $1910-1927$.

\begin{tabular}{|c|c|c|c|c|c|c|c|}
\hline \multicolumn{2}{|c|}{$\mathrm{m}^{3}$ per hectare } & 0 & $\mathbf{P}$ & $2 \mathrm{P}$ & PK & $2 \mathrm{PK}$ & Mineral soil \\
\hline & \multicolumn{7}{|c|}{ Grain yields } \\
\hline & 0 & 790 & 850 & 1000 & 2910 & 2740 & 1660 \\
\hline Clay & 100 & 1140 & 1830 & 1920 & 3120 & 3110 & 2220 \\
\hline , & 200 & 1170 & 2220 & 2310 & 3270 & 3320 & 2450 \\
\hline , & 300 & 1320 & 2550 & 2590 & 3400 & 3560 & 2680 \\
\hline , & 400 & 1680 & 2680 & 2710 & 3410 & 3560 & 2810 \\
\hline Sand & 100 & 850 & 1310 & 1710 & 3040 & 3190 & 2020 \\
\hline , & 200 & 940 & 1590 & 1780 & 3040 & 3300 & 2130 \\
\hline , & 300 & 900 & 1880 & 1760 & 3200 & 3520 & 2210 \\
\hline , & 400 & 1130 & 2190 & 2140 & 3310 & 3370 & 2430 \\
\hline Mean & & 1100 & 1900 & 1990 & 3180 & 3270 & 2270 \\
\hline
\end{tabular}

Fertilizing $122 * 160 * * 204 * * *$

Mineral soil $163 * 215 * * 274 * * *$

\begin{tabular}{|c|c|c|c|c|c|c|c|}
\hline & \multicolumn{7}{|c|}{ Straw yields } \\
\hline & 0 & 1310 & 2130 & 2090 & 3010 & 4790 & 2670 \\
\hline Clay & 100 & 1930 & 3240 & 3640 & 4740 & 5180 & 3740 \\
\hline , & 200 & 1960 & 3410 & 3730 & 4780 & 5130 & 3800 \\
\hline , & 300 & 1990 & 3500 & 3980 & 5120 & 5390 & 3990 \\
\hline , & 400 & 2490 & 3800 & 3820 & 4630 & 5030 & 3950 \\
\hline Sand & 100 & 1790 & 2470 & 3370 & 4780 & 5250 & 3520 \\
\hline , & 200 & 1550 & 2700 & 3200 & 4430 & 4840 & 3340 \\
\hline , & 300 & 1490 & 2710 & 3050 & 4050 & 4740 & 3200 \\
\hline , & 400 & 1560 & 2930 & 3430 & 4170 & 4870 & 3390 \\
\hline Mean & & 1780 & 2990 & 3360 & 4410 & 5020 & 3510 \\
\hline
\end{tabular}

Table 5. Average annual grain and straw yields of oats, kg per hectare, during the period $1928-1960$.

\begin{tabular}{|c|c|c|c|c|c|c|c|}
\hline \multicolumn{2}{|c|}{$\begin{array}{l}\text { Mineral soil, } \\
\mathrm{m}^{3} / \mathrm{ha}\end{array}$} & 0 & $\mathrm{P}$ & $2 \mathrm{P}$ & PK & $2 \mathrm{PK}$ & Mean \\
\hline & \multicolumn{7}{|c|}{ Grain yields (5 years) } \\
\hline & 0 & 1220 & 1240 & 1330 & 2530 & 2510 & 1760 \\
\hline Clay & 100 & 1560 & 2020 & 2340 & 2520 & 2620 & 2210 \\
\hline 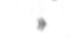 & 200 & 1580 & 2330 & 2390 & 2440 & 2490 & 2250 \\
\hline , & 300 & 1540 & 2460 & 2520 & 2540 & 2550 & 2320 \\
\hline , & 400 & 1580 & 2300 & 2470 & 2710 & 2600 & 2330 \\
\hline Sand & 100 & 1390 & 1510 & 1650 & 2450 & 2510 & 1900 \\
\hline 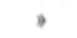 & 200 & 1360 & 1730 & 1780 & 2540 & 2430 & 1970 \\
\hline , & 300 & 1350 & 2040 & 1960 & 2680 & 2560 & 2120 \\
\hline " & 400 & 1430 & 2100 & 2040 & 2420 & 2280 & 2060 \\
\hline \multicolumn{2}{|l|}{ Mean } & 1450 & 1970 & 2050 & 2540 & 2510 & 2100 \\
\hline
\end{tabular}

Fertilizing $66 * 87 * * 111 * * *$

Mineral soil $89 * 120 * * 153 * * *$ 
Straw yields (4 years)

\begin{tabular}{|c|c|c|c|c|c|c|c|}
\hline & 0 & 1910 & 2370 & 2720 & 4270 & 4390 & 3130 \\
\hline Clay & 100 & 2580 & 3190 & 4130 & 4500 & 5260 & 3930 \\
\hline 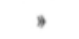 & 200 & 2680 & 3790 & 3800 & 4650 & 4440 & 3870 \\
\hline , & 300 & 2940 & 4120 & 4720 & 5110 & 4910 & 4240 \\
\hline , & 400 & 2760 & 4540 & 4700 & 5160 & 5120 & 4460 \\
\hline Sand & 100 & 2150 & 2930 & 3280 & 4630 & 4670 & 3530 \\
\hline , & 200 & 2120 & 2880 & 3080 & 4680 & 4720 & 3500 \\
\hline , & 300 & 2330 & 3120 & 3550 & 4770 & 5010 & 3760 \\
\hline , & 400 & 2550 & 3730 & 4370 & 4940 & 5190 & 4160 \\
\hline Mean & & 2450 & 3410 & 3820 & 4750 & 4860 & 3860 \\
\hline
\end{tabular}

Table 6. Average annual grain and straw yields of oats, kg per hectare, during the entire test period.

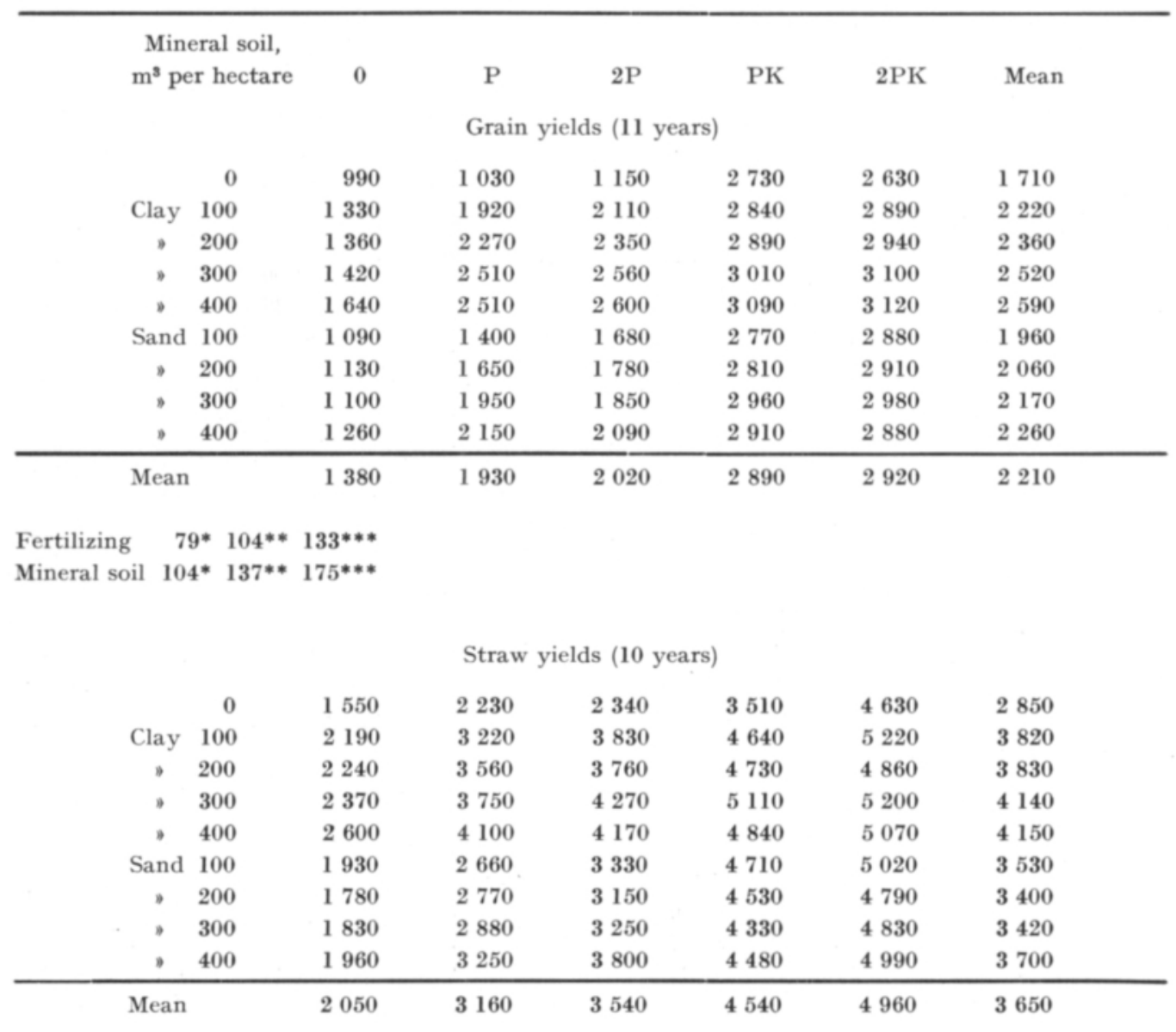

